SPORTIVE: Journal of Physical Education, Sport and Recreation

Volume 2 Nomor 2 Maret 2019

e-ISSN: 2597-7016 dan p-ISSN: 2595-4055

(c) (1) This work is licensed under a Creative Commons Attribution

4.0 International License

\title{
Pengaruh Kemampuan Fisik Terhadap Keterampilan smash \\ Dalam Permainan Bulutangkis
}

\section{Ilham Kamaruddin}

\section{Keywords :}

Physical fitnes, smash skill

Corespondensi Author

${ }^{1}$ Universitas Negeri Makassar

Email:

Ilham.kamaruddin@unm.ac.id

Article History

Received: 02-02-2019;

Reviewed: 14-02-2019;

Accepted: 25-02-2019;

Published: 20-03-2019

\section{ABSTRACT}

This research is descriptive research that aims to determine: (1) the physical fitnes of athletes badminton, (2) skill smash athlete badminton, (3) physical fitnes contributed to the smash skill in badminton. The population is all the athletes PB.Yanti Jaya Makassar totaling 40 people. Sampling technique was purposive sampling. The data analysis technique used is descriptive analysis, correlation coefficient analysis, and single regression analysis through SPSS 14, at significant level $\alpha$ $=0.05$. The results showed that: (1) the physical fitnes of in the category Enough with the average value of 200.05 , (2) Athlete Skills smash in the category Enough with the average value of 6.17 points; (3) There is a significant analysis of the physical components of the skill smash on Athletes badminton, the $R$ value of 0836 ( Pvalue $<0.05$ ) and accounted for $69.8 \%$.

Keywords: Physical fitnes, smash skill

\section{ABSTRAK}

Penelitian ini adalah jenis penelitian deskriptif yang bertujuan untuk mengetahui; (1) kemampuan fisik atlet bulutangkis; (2) keterampilan smash atlet bulutangkis;(3) kontribusi kemampuan fisik terhadap keterampilan smash dalam permainan bulutangkis atlet bulutangkis. Populasinya adalah seluruh atlet PB.Yanti Jaya Makassar yang berjumlah 40 orang. Teknik penentuan sampel adalah dengan purposive Sampling. Teknik analisis data yang digunakan adalah analisis deskriptif, analisis koefisien korelasi, dan analisis regresi tunggal melalui program SPSS 14 pada taraf signifikan $\alpha=0,05$. Hasil penelitian menunjukkan bahwa ; (1) Kemampuan fisik Atlet PB.Yanti Jaya Makassar berada pada kategori Cukup dengan nilai rata-rata sebesar 200,05; Keterampilan smash Atlet PB.Yanti Jaya Makassar 
Vol 2 No 2, Maret 2019

berada pada kategori Cukup dengan nilai rata-rata sebesar 6,17 poin; (3) Ada analisis yang signifikan antara komponen fisik terhadap keterampilan smash pada Atlet PB.Yanti Jaya Makassar, dengan nilai $R$ sebesar 0.836 $\left(P_{\text {value }}<\alpha 0,05\right)$ dan berkontribusi sebesar 69,8\%

Kata Kunci: Kemampuan fisik,smash 


\section{PENDAHULUAN}

Hakekat olahraga merupakan kegiatan fisik yang mengandung sifat permainan dan berisi perjuangan melawan diri sendiri atau dengan orang lain atau konfrontasi dengan unsur-unsur alam. Kegiatan olahraga meliputi gaya pertandingan, maka kegiatan itu harus dilaksanakan dengan semangat atau jiwa sportif. Pada olahraga kelompok mendorong manusia saling bertanding dalam suasana kegembiraan dan kejujuran. Olahraga memberi kemungkinan pada tercapainya rasa saling mengerti dan menimbulkan solidaritas serta tidak mementingkan diri sendiri. Olahraga juga dapat dijadikan alat pemersatu.

Selain itu olahraga juga dapat membuat tubuh seseorang menjadi sehat jasmani dan rohani yang akhirnya akan membentuk manusia yang berkualitas. Mengingat pentingnya peranan olahraga dalam kehidupan manusia, juga dalam usaha ikut serta memajukan manusia Indonesia berkualitas, maka pemerintah Indonesia mengadakan pembinaan dan pengembangan dibidang olahraga, seperti mengadakan pertandingan-pertandingan olahraga yang biasanya diikuti oleh para olahragawan seperti olahraga bulutangkis.

Cabang olahraga bulutangkis merupakan cabang olahraga yang sangat digemari oleh masyarakat pada umumnya, baik di perkotaan sampai ke pelosok pedesaan. Kepopuleran cabang olahraga ini sehingga hampir disetiap sudut ruang vano, ada dijumpai lapangan-lapangan bulutan 1 ; walaupun dalam bentuk yang sangat sederhana. Perbulutangkisan bagi bangsa Indonesia sudah merupakan cabang olahraga yang membawa nama harum bagi bangsa Indonesia. Hal ini terbukti dengan berhasilnya atlet-atlet bulutangkis kita meraih kemenangan dalam berbagai turnamen baik ditingkat Asean, Asia maupun ditingkat dunia dan lain sebagainya.
Di Sulawesi Selatan permainan bulutangkis sangat digemari oleh masyarakat ini terbukti banyaknya berdiri persatuan bulutangkis di daerah-daerah salah satunya di Kota Makassar. Atas dasar banyaknya masyarakat yang berminat menggeluti olahraga bulutangkis, sehingga olahraga bulutangkis ini dibentuk sebagai wadah pembinaan bagi atlet muda untuk menyalurkan bakatnya dibidang olahraga bulutangkis, maka pencita olahraga membentuk perkumpulan yang diberi nama atlet PB.Yanti Jaya Makassar.

Berdasarkan hasil survai dan pengamatan bahwa di PB.Yanti Jaya Makassar yang pemainnya begitu banyak yang latihan dan memiliki fasilitas olahraga yang memadai terutama lapangan bulutangkis, prestasi yang telah dicapai pada olahraga bulutangkis daerah ini cukup baik dan menunjukkan hasil yang sangat memuaskan dibandingkan dengan beberapa Persatuan Bulutangkis di Kota lain di Sulawesi Selatan. Hal ini terbukti dari beberapa kejuaraan daerah maupun yang pernah diselenggarakan di Makassar maupun di kawasan Sulawesi Selatan, dimana atlet-atlet dari PB.Yanti Jaya Makassar sering kali meraih prestasi, keberhasilan yang diraih didukung dengan faktor-faktor penunjang untuk menjadi lebih baik sudah diupayakan semaksimal mungkin. Namun prestasi yang diraih masih bersifat kejuaraan daerah.

Kejuaraan bulutangkis tingkat nasional sering dilaksanakan di Sulawesi Selatan seperti Pra PON, Milo dan Djarum Sirkuit Nasional sebagai ajang pencarian atlet bulutangkis berbakat dan pembuktian hasil latihan yang dilakukan. Setiap ada kejuaraan bulutangkis yang sifatnya kejuaraan daerah maupun kejuaraan nasional, PB.Yanti Jaya Makassar selalu mengikutkan atletnya baik yang diadakan di Sulawesi Selatan maupun di luar Sulawesi Selatan, tetapi hasil yang diraih masih kurang maksimal. Berdasarkan hasil yang diraih atlet PB.Yanti Jaya Makassar tersebut 
diduga karena kemampuan fisik yang dimilikinya kurang baik.

Keadaan seperti yang dikemukakan di atas merupakan salah satu masalah yang harus dicarikan jalan keluarnya, dan salah satu upaya yang dilakukan adalah melalui penelitian. Oleh sebab itu melalui penelitian ini menjadi wahana bagi penulis yang diharapkan dapat menunjang peningkatan prestasi olahraga bulutangkis. Kualitas permainan bulutangkis sangat tergantung pada penguasaan teknik dasarnya. Atlet atau pemain yang menguasai teknik dasar dengan baik akan dapat menampilkan permainan secara terampil. Dalam permainan bulutangkis terdiri dari beberapa teknik dasar, salah satu teknik dasar yang sangat berperan dan penting dikuasai oleh pemain adalah teknik smash.

Untuk mendapatkan smash yang baik dan menyulitkan lawan untuk mengembalikan coock dalam permainan bulutangkis maka diperlukan kemampuan dari gerakan-gerakan yang terkoordinir sehingga menampakkan satu kesatuan gerakan servis yang benar. Gerakan smash yang benar membutuhkan kemampuan fisik seperti kelentukan pergelangan tangan dan ketepatan memukul shuttellcock.

Pukulan smash, kemampuan fisik yang paling mempunyai pengaruh dominan adalah kelentukan pergelangan tangan. Kelentukan pergelangan tangan berperan untuk memperluas gerak persendian dan gerakan elastis dari otot-otot pergelangan tangan, sehingga gerakan servis pendek nampak lebih luwes dan tidak kaku. Selain itu, kelentukan pergelangan tangan juga dimanfaatkan untuk menambah kekuatan atau daya pada pergelangan tangan saat akan melakukan gerakan pukulan servis pendek sehingga akan memberikan gerakan tambahan secara cepat dan kuat. pukulan smash yang didukung dengan gerakan persendian pada pergelangan tangan akan menghasilkan pukulan yang tepat pada saasaran yang diinginkan. kelentukan pergelangan tangan yang kurang baik akan menyebabkan lemahnya daya dorong pada pergelangan tangan dan akan menghasilkan gerakan pukulan smash yang lemah dan tidak akurat sehingga mudah dikembalikan oleh lawan.

Peranan kemampuan fisik dalam menunjang prestasi olahraga seperti olahraga bulutangkis, tidak perlu diperdebatkan lagi, bagi yang memiliki kemampuan fisik yang tinggi tentu akan lebih berpeluang untuk berprestasi. Hal ini disebabkn karena tanpa kemampuan fisik yang memadai, maka teknik-teknik gerakan dalam permainan bulutangkis seperti halnya teknik smash tidak akan dapat dilakukan secara sempurna. Begitu pula sebaliknya bila kemampuan fisik baik maka pelaksanaan teknik akan dapat ditampilkan secara sempurna.

Kemampuan fisik tersebut terutama ditekankan pada bagian tubuh yang memegang peranan penting dalam melakukan pukulan smash, seperti kelentukan, daya ledak dan keseimbangan. Unsur fisik kelentukan adalah kemampuan pergerakan persendian dalam ruang gerak sendi dengan amplitudo yang lebih luas sehingga gerakan-gerakan yang dilakukan lebih mudah dan efisien. Dengan elastisitas otot-otot dan luasnya persendian seseorang akan lebih mudah menguasai keterampilan gerak seperti pada gerakan melakukan pukulan smash dalam permainan bulutangkis. koordinasi mata-tangan mempunyai peranan yang pentingnya di dalam melakukan smash, karena untuk menghasilkan smash yang keras dan tajam maka dibutuhkan kemampuan koordinasi mata-tangan yang baik, sebab smash yang keras dan tajam merupakan modal utama yang dapat mematikan pertahanan lawan dalam usaha meraih point. Olehnya itu koordinasi mata-tangan yang baik harus dimiliki oleh seorang pemain bulutangkis yang terampil.

Hal-

hal yang dikemukakan di atas merupakan dasar pemikiran penulis untuk dikembang berdasarkan berbagai faktor yang dapat menunjang keterampilan smash dalam permainan bulutangkis. Atas dasar pemikiran tersebut sehingga penulis bermaksud untuk mengadakan penelitian 
dengan judul "Analisis kemampuan fisik terhadap keterampilan smash dalam permainan bulutangkis atlet PB.Yanti Jaya Makassar". Kontribusi kemampuan fisik yang dimaksud dalam penelitian ini adalah kontribusi kelentukan pergelangan tangan, koordinasi mata-tangan dan daya ledak tungkai.

\section{Permainan Bulutangkis}

Permainan bulutangkis merupakan permainan yang bersifat individual yang dapat dilakukan dengan cara melakukan satu orang melawan satu orang atau dua orang melawan dua orang. Permainan ini menggunakan raket sebagai alat pemukul dan shuttle cock sebagai objek pukul, lapangan permainan berbentuk segi empat dan dibatasi oleh net untuk memisahkan antara daerah permainan sendiri dan daerah permainan lawan. Tujuan permainan bulutangkis adalah berusaha untuk menjatuhkan shuttle cock di daerah permainan lawan dan berusaha agar lawan tidak dapat memukul shuttle cock dan menjatuhkan didaerah permainan sendiri. Pada saat bermain berlangsung masingmasing pemain harus berusaha agar shuttle cock tidak menyentuh lantai di daerah permainan sendiri. Apabila shuttle cock jatuh di lantai atau menyangkut di net maka permainan berhenti (Herman Subardjah, $2000: 13$ )

a. Teknik dalam Bulutangkis

Istilah teknik adalah ketrampilan khusus atau skill yang harus dikuasai oleh pemain bulutangkis dengan tujuan mengembalikan shuttle cock dengan cara sebaik-baiknya. Teknik pukulan adalah cara-cara melakukan pukulan dalam permain bulutangkis dengan tujuan menerbangkang shuttle cock ke bidang lapangan lawan Seorang pemain bulutangkis yang baik dan berprestasi, dituntut untuk menguasai teknik-teknik pukulan dalam permainan bulutangkis.

Teknik-teknik itu meliputi:

a) Pukulan service.

Pukulan Service adalah pukulan dengan raket yang menerbangkan shuttle cock ke bidang lapangan lain secara diagonal dan bertujuan sebagai pembuka permainan. Menurut Ferry Sonneville yang dikutip Tohar (1992:41), melatih pukulan service dengan baik dan teratur, perlu mendapatkan perhatian yang baik dan khusus. Pukulan yang penting dan dilatih dengan baik serta teratur karena pemain yang melakukan sevice permainan akan mendapat angka. Sehingga setiap pemain harus mengusai teknik pukulan dengan baik. Pukulan service terdiri dari:

1) Service pendek atau short service Service pendek adalah service dengan mengarahkan shuttle cock dengan tujuan kedua sasaran yaitu kesudut titik perpotongan antara garis service depan dengan garis tengah dan garis service dengan garis tepi.

2) Service panjang atau service $l o b$ atau long service. Service panjang atau service lob adalah service dengan cara menerbangkan shuttle cock setinggitingginya dan jatuh ke garis belakang bidang lapangan lawan.

3) Service drive Service drive adalah service dengan cara menerbangkan shuttle cock secara keras, cepat mendatar dan setipis mungkin melewati net dan sejajar dengan lantai.

4) Service flik atau cambukan Service flik atau cambukan adalah service yang dilakukan dengan cara dicambukkan.

b) Pukulan $L o b$ atau clear.

Pukulan $l o b$ adalah suatu pukulan dalam permainan bulutangkis yang dilakukan dengan tujuan untuk menerbangkan shuttle cock setinggi mungkin mengarah ke belakang garis lapangan. Pukulan $l o b$ dapat dilaksanakan dengan 2 cara yaitu:

\section{1) Overhead lob}

Pukulan $l o b$ yang dilakukan dari atas kepala dengan cara menerbangkan shuttle cock melambung kearah belakang.

\section{2) Underhand lob}

Pukulan lob dari bawah yang berada dibawah badan dan dilambungkan tinggi ke belakang. 
c) Pukulan Dropshot

Pengertian pukulan drop dalam permainan bulutangkis menurut James Poole (1982:132) adalah pukulan yang tepat melalui jaring, dan langsung jatuh ke sisi lapangan lawan. Menurut Tohar (1992:50) pukulan dropshot adalah pukulan yang dilakukan dengan cara menyeberangkan shuttlecock ke daerah pihak lawan dengan menjatuhkan shuttle cock sedekat mungkin dengan net.

Pukulan dropshot dalam permainan bulutangkis sering disebut juga pukulan netting. Cara melakukan pukulan ini, pengambilan shuttle cock pada saat mencapai titik tertinggi di atas net sehingga pemukulannya secara dipotong atau diiris. Pukulan dropshot dapat dilakukan dari mana saja baik dari belakang maupun dari depan. Pukulan dropshot dapat dilakukan dengan 2 cara yaitu dropshot dari atas dan dropshot dari bawah. Pukulan dropshot dari atas ada beberapa cara melakukan yaitu:

1) Pukulan drop secara penuh

Pukulan drop secara penuh adalah pukulan drop yang dilakukan dengan cara datangnya shuttle cock dipukul secara tegak lurus terhadap perkenaan pada raket.

2) Pukulan drop potong atau iris

Pukulan drop potong atau iris adalah pukulan yang dilakukan dengan cara menerbangkan shuttle cock ke daerah lawan dengan menjatuhkan sedekat mungkin dengan net. Pukulan yang dilakukan pada saat menjelang shuttle cock tersentuh raket atau impact dengan raket.

3) Pukulan dropshot secara dicambuk atau flik

Pukulan drop yang dilakukan pada saat posisi shuttle cock berada diatas kepala dan raket diraihkan setingginya untuk memukul. Pada saat impact raket tidak dipotongkan tetapi dengan lurus pergelangan tangan dicambukkan untuk memukul shuttle cock.

\section{d. Pukulan Smash.}

Gerakan awal untuk pukulan smash hampir sama dengan pukulan lob. Perbedaan utama adalah pada saat akan impact yaitu pada pukulan lob shuttlecock diarahkan ke atas, sedang pada pukulan smash shuttlecock diarahkan tajam curam ke bawah mengarah ke bidang lapangan pihak lawan. Pukulan ini dapat dilaksanakan secara tepat apabila penerbangan shuttlecock di depan atas kepala dan diarahkan dengan ditukikkan serta diterjunkan ke bawah. Pukulan smash dapat dilakukan dengan cara:

1) Smash penuh

Yang dimaksud dengan pukulan smash penuh adalah melakukan pukulan smash dengan mengayunkan raket, perkenaannya tegak lurus antara daun raket dengan datangnya shuttle cock sehingga pukulan itu dilakukan secara penuh.

2)Smash dipotong.

smash dipotong adalah melakukan pukulan smash pada saat perkenaan antara ayunan raket dan penerbangan shuttle cock dilakukan secara dipotong atau diiris, sehingga kecapatan shuttle cock agak kurang cepat, tetapi daya luncurnya tajam dan lebih terarah.

3) Smash melingkar atau around the head smash

Smash melingkar adalah melakukan gerakan dengan mengayunkan tangan yang memegang raket, kemudian dilingkarkan melewati di atas kepala, dilanjutkan dengan menggerakkan pergelangan tangan dengan cara mencambukkan raket, sehingga melentingkan shuttle cock mengarah keseberang pihak lawan

\section{4) Smash cambukan atau flik smash.}

Smash cambukan adalah melakukan pukulan smash dengan cara mengaktifkan pergelangan tangan untuk melakukan cambukan secara ditekan ke bawah. Gerakan melakukan smash ini diawali dengan meluruskan lengan ke atas, pada saat impact ayunan lengan yang lurus sebagai gerak awal tetapi pada saat memukul, peranan yang utama bukan dari ayunan lengan atau tangan tetapi gerakan pergelangan tangan untuk dicambukkan secara dalam sehingga pergelangan tangan yang betul-betul aktif untuk menghujamkan shuttle cock ke bawah. 5) Backhand smash. 
Backhand

smash adalah melakukan pukulan smash yang dilakukan dengan menggunakan daun raket bagaian belakang sebagai alat pemukul. Pada saat memukul smash dengan cara ini posisi badan membelakangi net dengan mencambukkan pergelangan tangan yang diarahkan atau digerakkan menukik ke belakang.

\section{Keterampilan smash bulutangkis}

Pukulan smash adalah salah satu dari sekian teknik dasar pukulan yang ada pada permainan bulutangkis. Pukulan smash selama ini dianggap sebagai teknik dasar yang terakhir diberikan atau dipelajari setiap atlet bulutangkis, karena nanti semua teknik dasar lainnya dikuasai barulah pukulan smash diperbaiki atau dikuasai. Ini disebabkan karena pukulan smash adalah pukulan yang bertujuan untuk mematikan lawan atau mengakhiri suatu reli. Pukulan smash perlu diperhatikan tentang daya ledak, kelentukan, koordinasi, keseimbangan dan ketepatan mengarahkan bola dengan cepat dan terarah. Smash pada dasarnya mempunyai tujuan dan fungsi dari setiap cabang olahraga yaitu, mematikan pertahanan lawan atau mengakhiri suatu set reli. Ini diperkuat oleh pendapat James Poole (1982:35), mengemukakan bahwa: "Pukulan smash adalah adalah kekuatan seseorang pemain yang dapat mengumpulkan angka bagi anda dalam pertandingan".

Smash pada permainan bulutangkis adalah suatu pukulan yang keras dan tajam ke bawah mengarah ke bidang lapangan lawan. Pukulan ini dapat dilakukan secara tepat apabila penerbangan shuttlecock berada di depan atas kepala dan diarahkan dengan tukikan serta diterjunkan ke bawah secara keras dan tajam. Oleh karena smash adalah gerak kerja yang bertujuan untuk mematikan pertahanan lawan, maka perlu diperhatikan adalah kecepatan dan ketepatan dalam mengarahkan bola smash ke daerah lawan. Untuk lebih jelas tentang pukulan smash lihat gambar berikut.
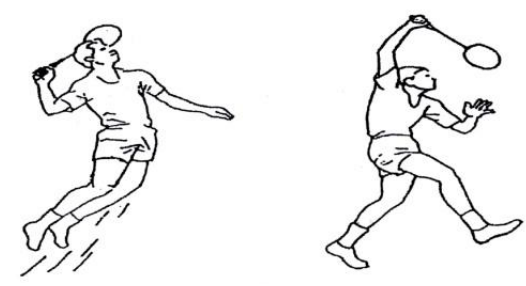

Gambar 1. Pukulan Smash

Sumber

\section{PB. PBSI (2002:30)}

\section{Kemampuan fisik}

Pembinaan prestasi olahraga yang bertujuan pencapaian prestasi secara optimal memerlukan pelatihan yang terprogram dengan baik dan berkesinambungan. Setiap cabang olahraga memerlukan status kemampuan fisik yang bervariasi perbedaanya satu sama lainya.

Berkaitan dengan praktikn pelatihan olahraga dalam upaya pencapaian prestasi yang optimal, harus disadari bahwa aspek-aspek fisik, teknik, strategi dan kematangan mental merupakan kesatuan yang harus selalu ditingkatkan. Untuk menentukan status kemampuan fisik dasar dan bersifat umum yang harus diberikan jauh sebelum program khusus. Macam-macam komponen kemampuan fisik yang perlu ditingkatkan dalam latihan adalah daya tahan kardiovaskuler, daya tahan kekuatan, kekuatan otot, kelentukan, kecepatan, stamina, kelincahan, dan power. (Harsono, 1988:100). Kemampuan fisik menurut M. Sajoto (1988: 16) adalah suatu kesatuan utuh dari komponen-komponen yang tidak dapat dipisahkan begitu saja, baik peningkatan maupun pemeliharaannya. Artinya bahwa didalam usaha peningkatan kemampuan fisik maka seluruh komponen tersebut harus dikembangkan, walaupun disana sini dilakukan dengan sistem prioritas sesuai keadaan atau status tiap komponen itu dan untuk keperluan apa keadaan atau status yang dibutuhkan tersebut.

$\begin{array}{ccr}\text { Khusus } & \begin{array}{c}\text { untuk smash } \\ \text { bulutangkis, }\end{array} & \text { dalam } \\ \text { menurut }\end{array}$


pelaksanaanya dapat diidentifikasikan ada dua komponen kemampuan fisik yang paling berperan, yaitu kelentukan pergelangan tangan, koordinasi mata-tangan dan daya ledak tungkai, sebab smash dalam permainan bulutangkis yang dalam pelaksanaannya dilakukan dengan cara melecutkan pergelangan tangan memerlukan koordinasi mata-tangan yang besar dan keseimbangan badan yang stabil pada saat melakukan pukulan smash.

\section{a. Kelentukan pergelangan tangan}

Kelentukan merupakan unsur fisik yang sangat penting dan diperlukan dalam semua cabang olahraga. Karena kelentukan menunjukkan kualitas yang memungkinkan suatu segmen persendian bergerak semaksimal mungkin menurut kemungkinan gerak (luasnya persendian) sehingga memingkinkan otot atau sekelompok otot untuk berkontraksi dalam posisi memendek dan memanjang secara maksimal. Dalam kontribusi tersebut, Abd. Adib Rani (1974:450) mengemukakan bahwa "Flaksibility adalah suatu kemampuan seseorang melakukan gerakan dengan amplitudo yang luas".

Kualitas kelentukan tubuh ditentukan oleh elastisitas otot-otot, tendo atau jaringan pengikat. Dengan demikian dapat dikatakan bahwa seseorang yang memiliki otot yang elastis. Namun elastisitas otot dapat berkurang apabila tidak melakukan latihan dalam jangka waktu yang lama. Latihan-latihan yang dapat meningkatkan kelentukan dapat berupa latihan-latihan penguluran (stretching). Dapat pula dikatakan bahwa kelentukan merupakan kemampuan melakukan gerakan dalam ruang gerak sendi, sebagaimana yang dikemukakan oleh Harsono (1988:163) bahwa "Kelentukan adalah kemampuan untuk melakukan gerakan dalam ruang gerak sendi. Kecuali oleh ruang gerak sendi, kelentukan juga ditentukan oleh elastitis tidaknya otot-otot, tendo, dan ligamen". Selain itu dikemukakan oleh Rahantoknam (1988:125) bahwa "Fleksibilitas merupakan rentang gerak persendian yang ada pada satu atau sekelompok persendian". Dengan elastisitas otot-otot dan luasnya persendian seseorang akan lebih mudah menguasai keterampilan gerak dalam berbagai cabang olahraga dan lebih cepat, karena kemungkinan geraknya akan lebih leluasa dan gerakan-gerakan yang sulit dapat dilakukannya.

Menurut jenis kelentukan Rahantoknam (1988: 125) membagi ke dalam dua bagian yaitu:Fleksibilitas statis melalui rentang gerak sederhana seperti tunduk perlahan-perlahan dan sentuh ubin. Fleksibilitas dinamis adalah kecakapan untuk menggunakan rentang sendi dalam penampilan kegiatan fisik dengan tingkat kecepatan yang diperlukan dalam penampilan.

\section{METODOLOGI PENELITIAN}

Metode atau cara yang digunakan dalam penelitian ini adalah metode penelitian "Deskriptif" dengan teknik regresi, yaitu mencari kontribusi antara variabel-variabel yang satu dengan variabel lainnya. Seperti yang dikatakan Sukmadinata, (2006:73) bahwa "Penelitian deskriptif tidak memberikan perlakuan, manipulasi atau pengubahan pada variabelvariabel bebas, tetapi menggambarkan suatu kondisi apa adanya". Adapun Rancangan/desain penelitian yang digunakan adalah "Model Regresional"

Data yang terkumpul melalui tes masih merupakan data kasar. Data tersebut selanjutnya dianalisis dengan menggunakan uji statistik korelasional dengan bantuan paket SPSS dalam komputer. Analisis yang dimaksud dalam penelitian ini adalah analisis deskriptif untuk menggambarkan data apa adanya dan analisis infrensial untuk menguji hipotesis dengan menggunakan analisis korelasi sederhana dan analisis korelasi ganda. Untuk analisis korelasi sederhana dan analisis korelasi ganda terlebih dahulu dilakukan analisis normalitas dengan menggunakan 
Kolmogorov Smirnov (KS-Z) dan program SPSS.

\section{HASIL PENELITIAN DAN PEMBAHASAN}

1. Analisis Deskriptif

Untuk mendapatkan gambaran umum data suatu penelitian maka digunakanlah analisis data deskriptif. Analisis deskriptif dilakukan terhadap komponen fisik ditinjau dari Koordinasi mata-tangan, daya ledak tungkai, dan kelentukan togok kebelakang kelentukan pergelangan tangan dan keterampilan smash pada Atlet PB.Yanti Jaya MAKASSAR. Hal ini dimaksudkan untuk memberi makna pada hasil analisis yang telah dilakukan. Hasil analisis deskriptif data tersebut dapat dilihat pada tabel 1:

Tabel 1. Rangkuman hasil analisis deskriptif data komponen fisik dan keterampilan smash pada atlet PB.Yanti Jaya Makassar.

\begin{tabular}{|l|r|r|c|c|c|}
\hline $\begin{array}{l}\text { Nilai } \\
\text { statistic }\end{array}$ & $\begin{array}{c}\text { Koordi } \\
\text { nasi } \\
\text { mata- } \\
\text { tangan }\end{array}$ & $\begin{array}{c}\text { Kelen } \\
\text { Daya } \\
\text { ledak } \\
\text { tungka } \\
\text { tukan } \\
\text { perge } \\
\text { langa } \\
\mathrm{n} \\
\text { tanga } \\
\mathrm{n}\end{array}$ & $\begin{array}{c}\text { Komp } \\
\text { onen } \\
\text { fisik }\end{array}$ & $\begin{array}{c}\text { Smas } \\
\mathrm{h}\end{array}$ \\
\hline Mean & 5.07 & 43.62 & 73.32 & 200.05 & 6.17 \\
Std. & 1.85 & 8.80 & 4.22 & 31.62 & 2.19 \\
Deviation & 6.00 & 36.00 & 14.00 & 126.66 & 8.00 \\
Range & 2.00 & 24.00 & 65.00 & 142.71 & 2.00 \\
Minimum & 8.00 & 60.00 & 79.00 & 269.37 & 10.00 \\
Maximum
\end{tabular}

Tabel 1, merupakan gambaran data komponen fisik aspek Koordinasi matatangan, daya ledak tungkai, dan kelentukan togok kebelakang kelentukan pergelangan tangan dan keterampilan smash pada atlet PB.Yanti Jaya Makassar. Untuk lebih jelasnya diuraikan sebagai berikut:

1) Untuk data komponen fisik ditinjau dari aspek Koordinasi mata-tangan diperoleh skor rata-rata (mean) $=5,07$ kali, simpangan baku (standar deviasi) $=1,85$ kali, nilai terendah $($ minimum $)=2$ kali, dan nilai tertinggi $($ maksimum $)=8$ kali.

2) Untuk data komponen fisik ditinjau dari aspek daya ledak tungkai diperoleh skor rata-rata $($ mean $)=43,62 \mathrm{~cm}$, simpangan baku (standar deviasi) $=8,80 \mathrm{~cm}$, nilai terendah $($ minimum $)=24 \mathrm{~cm}$, dan nilai tertinggi $($ maksimum $)=60 \mathrm{~cm}$.

3) Untuk data komponen fisik ditinjau dari aspek kelentukan pergelangan tangan diperoleh skor rata-rata $($ mean $)=73,32$, simpangan baku (standar deviasi) = 4,22 , nilai terendah $($ minimum $)=65$, dan nilai tertinggi $($ maksimum $)=79$.

4) Untuk data komponen fisik diperoleh skor rata-rata (mean) $=200,05$, simpangan baku (standar deviasi) $=$ 31,62, nilai terendah (minimum) $=$ 142,71 , dan nilai tertinggi $($ maksimum $)=$ 269,37 .

5) Untuk data Keterampilan smash, diperoleh nilai rata-rata (mean) $=6,17$ poin, simpangan baku (standar deviasi) $=2,19$ poin, nilai terendah $($ minimum $)=$ 2 poin, dan nilai tertinggi $($ maksimum $)=$ 8 poin.

\section{Pengujian Normalitas Data}

Salah satu persyaratan yang harus dipenuhi agar statistik parametrik dapat digunakan dalam menganalisis data penelitian adalah data harus mengikuti sebaran normal (berdistribusi normal). Untuk mengetahui apakah data komponen fisik ditinjau dari Koordinasi mata-tangan, daya ledak tungkai, dan kelentukan togok kebelakang kelentukan pergelangan tangan dan keterampilan smash pada atlet PB.Yanti Jaya Makassar berdistribusi normal, maka dilakukan uji normalitas data dengan menggunakan uji Kolmogorov Smirnov. Hasil uji normalitas dapat dilihat pada tabel 2. berikut ini:

Tabel 2. Rangkuman hasil uji normalitas data. 
Vol 2 No 2, Maret 2019

$\underset{\text { pengujian normalitas tabel 2, maka }}{\text { Berdasarkan }}$ menggunakan uji Kolmogrov-Smirnov (KS-

Z) menunjukkan hasil sebagai berikut:

1) Untuk data komponen fisik ditinjau aspekKoordinasi mata-tangan, daya ledak tungkai, dan kelentukan togok kebelakang kelentukan pergelangan tangan dan keterampilan smash pada atlet PB.Yanti Jaya Makassar diperoleh nilai $\mathrm{KS}-\mathrm{Z}=0,793 \quad(\mathrm{P}=0,556>$ $\alpha 0,05)$, sehingga dapat disimpulkan bahwa data komponen fisik ditinjau dari daya Koordinasi mata-tangan, daya ledak tungkai, dan kelentukan togok kebelakang kelentukan pergelangan tangan dan keterampilan smash pada atlet PB.Yanti Jaya Makassar mengikuti sebaran normal atau berdistribusi normal.

Untuk data keterampilan smash, diperoleh nilai $\mathrm{KS}-\mathrm{Z}=0,931(\mathrm{P}=0,351>\alpha 0,05)$, sehingga dapat disimpulkan bahwa data Keterampilan smash mengikuti sebaran normal atau berdistribusi normal.

Untuk pengujian hipotesis tersebut maka dilakukan uji regresi antara data kelincahan, keseimbangan, dan kecepatan reaksi kaki terhadap keterampilan menggiring bola dengan menggunakan tehnik Regresi Pearson. Hasil analisis regresi akan dijelaskan sebagai berikut :

Variabel Komponen fisik Dinjau dari aspek kelentukan togok kebelakang diungkap dengan jalan memberikan penilaian atas kelentukan togok kebelakang, setelah dilakukan penilaian dan dianalisis dengan menggunakan statistic deskriptif frekuensi,

Dari hasil penelitian dapat diketahui atlet memiliki komponen fisik yang termasuk dalam kategori sangat baik sebanyak 3 orang dengan persentase 7,5\%, yang yang termasuk dalam kategori baik sebanyak 13 orang dengan persentase $32,5 \%$, atlet yang termasuk dalam kategori cukup sebanyak 9 orang dengan persentase $22,5 \%$, atlet yang termasuk dalam kategori kurang sebanyak 13 orang dengan persentase $32,5 \%$, dan atlet yang termasuk

\begin{tabular}{|c|c|c|}
\hline $\begin{array}{c}\text { Nilai } \\
\text { Statistik }\end{array}$ & $\begin{array}{c}\text { Komponen } \\
\text { Fisik }\end{array}$ & $\begin{array}{c}\text { Keterampilan } \\
\text { smash }\end{array}$ \\
\hline $\begin{array}{l}\text { Kolmogorov- } \\
\text { Smirnov Z }\end{array}$ & 0,793 & 0,931 \\
\hline Asymp. Sig. & 0,556 & 0,351 \\
\hline Keterangan & Normal & Normal \\
\hline
\end{tabular}

Variabel keterampilan smash diungkap dengan jalan memberikan penilaian atas tes smash, setelah dilakukan penilaian dan dianalisis dengan menggunakan statistic deskriptif frekuensi, diperoleh nilai-nilai sampel seperti pada tabel di bawah ini.

Hasil penelitian dapat diketahui atlet memiliki keterampilan smash yang termasuk dalam kategori sangat baik sebanyak 3 orang dengan persentase 7,5\%, yang yang termasuk dalam kategori baik sebanyak 11 orang dengan persentase $27,5 \%$, atlet yang termasuk dalam kategori cukup sebanyak 13 orang dengan persentase $32,5 \%$, atlet yang termasuk dalam kategori kurang sebanyak 10 orang dengan persentase $25 \%$, dan atlet yang termasuk dalam kategori kurang sekali sebanyak 3 orang dengan persentase $7,5 \%$

Untuk mengetahui keterkaitan antara komponen fisik dengan keterampilan smash dalam permainan bulutangkis atlet PB.Yanti Jaya Makassar, maka perlu dianalisis dengan menggunakan analisis regresi. Untuk lebih jelasnya, maka rangkuman hasil analisis korelasi ganda dapat dilihat dari regresi data komponen fisik dan keterampilan smash dalam permainan bulutangkis atlet PB.Yanti Jaya Makassar pada Tabel 13 Diperoleh nilai korelasi (r) 0,836 dengan tingkat probabilitas $(0,000)<\alpha 0,05$, untuk nilai $\mathrm{R}$ Square (koefisien determinasi) 0,698. Hal ini berarti $69,8 \%$ keterampilan smash dalam permainan bulutangkis dijelaskan oleh komponen fisik. Sedangkan sisanya dijelaskan oleh sebab-sebab yang lain. Dari uji Anova atau $\mathrm{F}$ test, didapat $\mathrm{F}$ hitung adalah 87,950 dengan tingkat signifikansi 0,000 . Oleh karena probabilitas $(0,000)$ jauh 
lebih kecil dari $\alpha 0,05$, maka model regresi dapat dipakai untuk memprediksi keterampilan smash dalam permainan bulutangkis (dapat diberlakukan untuk populasi dimana sampel diambil). Maka koefisien regresi signifikan, atau komponen fisik benar-benar berpengaruh secara signifikan terhadap keterampilan smash dalam permainan bulutangkis. Dengan demikian ada hubungan antara komponen fisik terhadap keterampilan smash dalam permainan bulutangkis atlet PB.Yanti Jaya Makassar, dan memberikan kontribusi sebesar $69,8 \%$ terhadap keterampilan smash.

\section{B. Pembahasan}

Hasil-hasil analisis kontribusi antara kedua variable bebas terhadap varuabel terikat dalam pengujian hipotesis perlu dikaji lebih lanjut dengan memberikan interpretasi keterkaitan antara hasil analisis yang dicapai dengan teori-teori yang mendasari penelitian ini. Penjelasan ini diperlukan agar dapat diketahui kesesuaian teori-teori yang dikemukakan dengan hasil penelitian yang diperoleh. Adapun penjelasan untuk memberikan kejelasan keterkaitan variable-variabel bebas terhadap variable terikat adalah sebagai berikut:

Hasil-hasil analisis dalam hipotesis perlu dikaji lebih lanjut dengan memberikan interpretasi keterkaitan antara hasil analisis yang dicapai dengan teori-teori yang mendasari penelitian ini. Penjelasan ini diperlukan agar dapat diketahui kesesuaian teori-teori yang dikemukakan dengan hasil penelitian yang dicapai. Untuk mengambil kesimpulan penelitian yang sesuai dengan tujuan penelitian, maka hasil analisis data yang perlu dibahas sesuai dengan teori-teori yang mendasarinya. Adapun pembahasan yang dimaksud adalah sebagai berikut:

Berdasarkan hasil penelitian dapat diketahui atlet memiliki komponen fisik ditinjau dari Koordinasi mata-tangan termasuk dalam kategori sangat baik sekali sebanyak 4 orang dengan persentase $10 \%$, yang yang termasuk dalam kategori baik sebanyak 13 orang dengan persentase $32,5 \%$, atlet yang termasuk dalam kategori cukup sebanyak 6 orang dengan persentase $15 \%$, atlet yang termasuk dalam kategori kurang sebanyak 14 orang dengan persentase $35 \%$, dan atlet yang termasuk dalam kategori kurang sekali sebanyak 3 orang dengan persentase $7,5 \%$. Pada unsure Koordinasi mata-tangan ditemukan atlet yang berada pada kategori kurang dan kurang sekali rendahnya hasil tes Koordinasi mata-tangan ini, dipengaruhi oleh aktifitas atlet yang begitu padat sebelum melakukan tes sehingga banyakkonsentrasi dan energy yang terkuras sebelum tes dilaksanakan. Porsi latihan yang dianggap masih kurang juga merupakan factor yang mempengaruhinya. Koordinasi mata-tangan sangat dibutuhkan dalam pelaksanaan smash. Pada saat melakukan smash tubuh ini hanya berdiri dengan satu kaki. Dalam keadaan seperti ini tubuh memerlukan Koordinasi mata-tangan untuk mempertahankan posisi tubuh agar dapat melakukan smash dengan baik dan benar. Hal ini menendakan bahwa seseorang yang memiliki Koordinasi matatangan yang baik akan dapat membantu dalam melaksanakan smash.

atlet memiliki komponen fisik ditinjau dari daya ledak tungkai termasuk dalam kategori sangat baik sebanyak 5 orang dengan persentase $12,5 \%$, yang yang termasuk dalam kategori baik sebanyak 7 orang dengan persentase $17,5 \%$, atlet yang termasuk dalam kategori cukup sebanyak 17 orang dengan persentase $42,5 \%$, atlet yang termasuk dalam kategori kurang sebanyak 10 orang dengan persentase $25 \%$, dan atlet yang termasuk dalam kategori kurang sekali sebanyak 1 orang dengan persentase 2,5\%. Ada banyak factor yang mempengaruhi atlet PB.Yanti Jaya sehingga hasil yang dapat dalam penelitian ada yang berada pada kategori kurang dan kurang sekali. Ratarata atlet tersebut pada saat dilakukan penelitian kondisi tubuhnya tidak dalam keadaan prima, yang mana baru selesai melakukan aktifitas sekolah sehingga hal ini dapat mempengaruhi hasil tesnya. Selain itu factor latihan yang kurang membebankan pada latihan fisik juga sangat berpengaruh 
terhadap hasil tes. Sementara apa yang kita ketahui bahwa daya ledak tungkai sangat menunjang keterampilan smash, pada saat melakukan smash diperlukan kekuatan dan kecepatan yang berpadu menjadi satu untuk menyepak bola sekeras-kerasnya kedaerah sasaran smash yang sah. Dengan daya ledak tungkai, pemain dapat melompat setinggitingginyauntuk dapat melakukan smash. Semakin tinggi lompatan seseorang maka akan semakin mudah mengarahkan pukulan smash dan semakin memperpendek jatuhnya bola pada saat dismash. Oleh karena itu daya ledak tungkai sangat mendukung pelaksanaan smash yang akurat.

atlet memiliki komponen fisik ditinjau dari kelentukan togok kebelakang termasuk dalam kategori sangat baik sebanyak 2 orang dengan persentase $5 \%$, yang yang termasuk dalam kategori baik sebanyak 11 orang dengan persentase $27,5 \%$, atlet yang termasuk dalam kategori cukup sebanyak 1 lorang dengan persentase $27,5 \%$, atlet yang termasuk dalam kategori kurang sebanyak 16orang dengan persentase $340 \%$, dan tidak ada atlet yang termasuk dalam kategori kurang sekali Kelentukan togok kebelakang juga sangat mendukung pelaksanaan smash. Gerak badan yang lentuk dalam melakukan gerakan smash pada permainan bulutangkis adalah yang gerakan yang dapat membantu atau menambah tenaga saat melakukan smash. Semakin lentuk seseorang maka ruang gerak sendinya akan semakin besar, dan semakin besar ruang gerak sendinya maka akan semakin besar pula tenaga yang dihasilkannya saat melakukan smash. Untuk itu kelentukan togok kebelakang sangat di butuhkan dalam melaksanakan pukulan smash . Dalam penelitian ini juga atlet memiliki komponen fisik ditinjau dari kelentukan pergelangan tangan termasuk dalam kategori baik sebanyak 15 orang dengan persentase $37,5 \%$, atlet yang termasuk dalam kategori cukup sebanyak 13 orang dengan persentase $32,5 \%$, atlet yang termasuk dalam kategori kurang sebanyak 9 orang dengan persentase $22,5 \%$, atlet yang termasuk dalam kategori kurang sekali sebanyak 3 orang dengan persentase 7,5\%. dan tidak terdapat atlet yang termasuk dalam kategori baik sekali. masih adanya atlet yang didapati memiliki kelentukan pergelangan tangan yang berada pada kategori kurang sekali adalah hal yang harus menjadi perhatian besar oleh pelatihnya untuk lebih memberikan latihan yang yang dapat meningkatkan hasil kelentukan pergelangan tangannya karena seperti yang kita ketahui Kelentukan pergelangan tangan adalah salah satu factor yang dapat menunjang terjadinya smash yang tajam dan curam.

Berdasarkan hasil pengujian analisis regresi data komponen fisik dan keterampilan smash dalam permainan bulutangkis atlet PB.Yanti Jaya Makassar pada Tabel 13 Diperoleh nilai korelasi (r) 0,836 dengan tingkat probabilitas $(0,000)$ $<\alpha 0,05$, untuk nilai R Square (koefisien determinasi) 0,698. Hal ini berarti 69,8\% keterampilan smash dalam permainan bulutangkis dijelaskan oleh komponen fisik. Sedangkan sisanya dijelaskan oleh sebab-sebab yang lain. Dari uji Anova atau $\mathrm{F}$ test, didapat $\mathrm{F}$ hitung adalah 87,950 dengan tingkat signifikansi 0,000. Oleh karena probabilitas $(0,000)$ jauh lebih kecil dari $\alpha$ 0,05, maka model regresi dapat dipakai untuk memprediksi keterampilan smash dalam permainan bulutangkis (dapat diberlakukan untuk populasi dimana sampel diambil). Maka koefisien regresi signifikan, atau komponen fisik benar-benar berpengaruh secara signifikan terhadap keterampilan smash dalam permainan bulutangkis. Dengan demikian ada hubungan antara komponen fisik terhadap keterampilan smash dalam permainan bulutangkis atlet PB.Yanti Jaya Makassar, dan memberikan kontribusi sebesar $69,8 \%$ terhadap keterampilan smash. Hasil penelitian tes komponen fisik diketahui secara keseluruhan, sebagian besar atlet PB.Yanti Jaya Makassar dapat disimpulkan bahwa hasil tes komponen fisik pada Atlet PB.Yanti Jaya Makassar 
dapat dikategorikan cukup dengan hasil rata-rata nilai 200,05 (hasil deskriptif data). Salah satu faktor yang mempengaruhi keberhasilan seorang atlet mengenai komponen fisiknya adalah faktor latihan. Latihan adalah sesuatu proses berlatih yang sistematis, yang dilakukan berulang-ulang dan yang kian hari jumlah beban latihannya kian bertambah. Kemampuan seseorang untuk melakukan sesuatu seringkali harus didukung dengan latihan yang keras.

\section{KESIMPULAN DAN SARAN}

Kesimpulan

Berdasarkan analisis data dan pembahasannya, maka hasil penelitian ini dapat dikesimpulan sebagai berikut:

1. Kemampuan fisik Atlet PB.Yanti Jaya Makassar berada pada kategori Cukup dengan nilai rata-rata sebesar 200,05

2. Keterampilan smash Atlet PB.Yanti Jaya Makassar berada pada kategori Cukup dengan nilai rata-rata sebesar 6,17 poin.

3. Ada kontribusi yang signifikan antara komponen fisik terhadap keterampilan smash pada Atlet PB.Yanti Jaya Makassar..

Saran

Berdasarkan hasil analisis data dan kesimpulan, maka dapat dikemukakan saran-saran sebagai berikut:

1. Bagi para guru penjas, pembina dan pelatih cabang olahraga bulutangkis, bahwa kiranya dalam upaya untuk meningkatkan keterampilan smash bagi atlet atau atlet yang dibina, hendaknya perlu memperhatikan unsur komponen fisik yang dapat menunjang, seperti Koordinasi mata-tangan, daya ledak tungkai, kelentukan pergelangan tangan.

2. Bagi para atlet atau atlet cabang olahraga sepakbola, direkomendasikan bahwa atlet atau atlet perlu membekali diri mengenai pengetahuan tentang pentingnya mengembangkan dan memiliki komponen fisik seperti Koordinasi mata-tangan, daya ledak tungkai, kelentukan pergelangan tangan dan kelentukan togok kebelakang guna dapat lebih meningkatkan keterampilan smash dengan maksimal.

3. Peneliti menyarankan kepada peneliti yang akan datang untuk lebih menyempurnakan penelitian ini dengan melengkapi dari empat aspek komponen fisik yang sudah diteliti.

\section{DAFTAR PUSTAKA}

Arikunto Suharsimi, 1996. Prosedur penelitian suatu pendekatan praktek. Penerbit Rineka Cipta, Jakarta.

Badaru,Benny. ( 2008 ).Skripsi: Hubungan Kelentukan Pergelangan Tangan Dan Daya Peras Tangan Dengan kemampuan Srervis Panjang Siswa Fik Unm. Makassar

Barrow, Harold M. dan McGee. Rosemary. 1979. A Practical Approach to measurement in Physical education. Philadelphis: Lea \& Febiger

Fox, EL.Dkk., 1988. The Psycological Basic Of Physical Education Athletics. New York, Sounders Collage Publishing.

Hadi Sutrisno. 1990. Analisis regresi. Penerbit Andi Off set, Yokyakarta.

Halim Ichsan Nur. 2004. Tes dan Pengukuran Kesegaran Jasmani. Cetakan Pertama. Badan Penerbit Unversitas Negeri Makassar. Makassar

Harre. D. 1982. Principle Of Sport Training. Introducttion To Theory Of Methodes Of Training. Sportverlag. Berlin

Harsono. 1988. Coaching dan aspek-aspek psikologis dalam coaching. Depdikbud Dirjen P2LPTK, Jakarta.

Herman Subarjah. 2000. Bulutangkis. Jakarta. Dirjen Dikti PPLPTK Depdikbu RI 
Ismariati. 2006. Tes dan Pengukuran Olahraga. Solo. Sebelas Maret University Press.Jasep Nossek, 1982. General Theory of Training Lagos: Pan African Press Ltd, 1982),

Johnson B.L. \& J, K. Nelson, 1986.

Practical Measurement for Evaluation in physical Education. New York : Mac Milan Publishing Company

Kadir, Ateng. Abdul, 1992 Asas dan Landasan Pendidikan Jasmani. Jakarta. Dirjen Dikti PPLPTK Depdikbu RI.

Kamaruddin, Ilham. 2019. Beladiri Anggar. Nas Media Pustaka. Makassar

Kamaruddin, Ilham . 2019. Application of Massed Practice Method and Motoric Ability to Fencing Martial Skills .Advances in Social Science. Education and Humanities Research (ASSEHR), volume 227. 1st International Conference on Advanced Multidisciplinary Research (ICAMR 2018). h. 145-147

Lafayette Instrument. 2006. Manual Instrumen ACUMAR" Digital Inclinometer.

Pujianto., dkk. 1979. Dasar Bermain Bulutangkis. Penerbit Klaten.

Sajoto, Moch.1988.Pembinaan Kemampuan fisik Dalam Olahraga. Semarang : FPOK IKIP

Sugiyono, 1999. Statistika Untuk Penelitian. CV. Alfabeta, Bandung

Tohar. 1992. Olahraga Pilihan Bulutangkis. Depdikbud Dirjen Pendidikan Tinggi. Proyek Pembinaan tenaga Kependidikan. Jakarta.

Thomas, J.R., Nelson, J.K., 1990. Research Methods In Physical Activity. Human Kinetic Book, Champaign, Illinois.

Tony Grice. 2007. Bulutangkis : Petunjuk untuk pemula dan lanjutan. Penerbit PT. Rajagrafindo Persada, Jakarta

Ferry Sonneville.1985. Bulutangkis Bermutu. Terjemahan Tan Liang
Tie. Penerbit PT. Keng Po, Pintu besar Selatan 86-88. Jakarta.

Verducci, Frank, M. 1980.Measurement Concept In Physical Education. San Fransisco, California : The C.V Mosby Company 